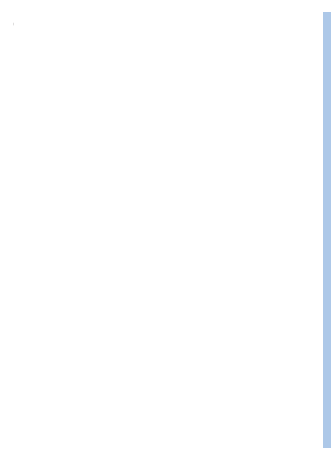

Zubyk A. I

\section{Journal of Geology, Geography and Geoecology} Journal home page: geology-dnu.dp.ua
Journ. Geol. Geograph.
Geology,
$30(4), 794-807$.
doi: $10.15421 / 112173$

Journ. Geol. Geograph.
Geology,
$30(4), 794-807$.
doi: $10.15421 / 112173$

Journ. Geol. Geograph.
Geology,
$30(4), 794-807$.
doi: $10.15421 / 112173$

ISSN 2617-2909 (print)

ISSN 2617-2119 (online)

\title{
Ukrainians in Belarus: distribution and ethnolinguistic processes
}

Andrii I. Zubyk

Lviv National Ivan Franko University, Lviv, Ukraine, andriy.zubyk@Inu.edu.ua

Received: 28.01.2021

Received in revised form: 08.02.2021

Accepted: 11.02.2021

Abstract. The article analyzes the distribution and ethnolinguistic processes in the environment of the Ukrainian diaspora in Belarus. Because of the fact that the part of Ukrainian ethnic territory (currently Brest region) is located in Belarus, not all Ukrainians living in the country can be correctly named a diaspora. To avoiding terminology-related complications, in the article we use the general term Ukrainian diaspora. The study is based on the results of censuses conducted in Belarus after 1991. The article analyzes the ethnic environment of residence of the Ukrainian diaspora based on the ethnocultural and ethnolinguistic criteria of the censuses. In particular, using mathematical and statistical methods of analysis of the ethnic composition of the country's population, we estimated such indicators as the index of ethnic diversity, ethnic mosaic, socio-ethnic density, etc. These indicators were estimated for districts and the largest cities of Belarus, taking into account the largest ethnic groups living in the country. The result of these estimations was the creation of a number of thematic maps that complement the article. The study highlights the areas of compact residence of Ukrainians, identifies districts and cities where the number of Ukrainians changed the most and the least during the inter-census periods of 1999-2009 and 2009-2019. The dynamics of the number and settlement of Ukrainians in the Ukrainian ethnic territories is analyzed. In this context, it was found that in addition to the Brest region, there is a dense concentration of Ukrainians in the capital, major cities of the country, a number of district centers in the southwestern part of the country. It was determined that the share of Ukrainians living in cities is growing. The growth rate of the number of Ukrainians for the period between 2009 and 2019 in the largest cities of the country ranges from $+7 \%$ (Mogilev) to $77.45 \%$ (Novopolotsk). It was found that the country is monoethnic in its ethnic composition based on the analysis of a number of indicators related to the ethnic composition of the population of Belarus. A more diverse ethnic composition of the population and therefore higher rates were recorded in large cities and areas densely populated with individual ethnic groups (Russians, Poles and Ukrainians). The Ukrainian diaspora in the country is undergoing processes of Russification, the share of Ukrainians who indicate Ukrainian as their mother tongue is declining. The share of Ukrainians whose native language is Belarusian is also declining. That is, it can be argued that Russification affects not only Ukrainians in Belarus, but also the Belarusians themselves. The research also revealed that villagers are more resistant to language assimilation, and Ukrainians in cities most often indicate Russian as their native language.

Keywords: Ukrainian diaspora, census of population, distribution, nationality, assimilation, ethnolinguistic processes.

\section{Українці в Білорусі: розселення та етномовні процеси}

\section{Зубик А. I.}

Львівський національний університет імені Івана Франка, Львів, Украӥна, andriy.zubyk@lnu.edu.ua

Анотація. Стаття присвячена дослідженню розселення та етномовних процесів в українській діаспорі Білорусі. Вихідними даними для цієї статті є результати переписів населення країни, проведених після розпаду Радянського Союзу. Аналіз здійснено за такими критеріями перепису населення, як «національність», «рідна мова» та «мова, якою розмовляють удома». Дані про національний склад населення в розрізі районів та найбільших міст Білорусі дали змогу обчислити та закартографувати індекс етнічного різноманіття, етнічної мозаїчності, показника соціоетнічної щільності, коефіцієнта етнічної спільності та етнічної компактності. У процесі дослідження встановлено, що попри тенденції скорочення чисельності української діаспори у країнах колишнього Радянського Союзу, чисельність українців у Білорусі зросла. Проаналізовано відносні та абсолютні зміни в розселенні українців у розрізі районів та найбільших міст країни, виділено території, де зафіксовано найбільші та найменші показники. Вдалося визначити, що порівняно з 2009 р. зросла частка українців, які проживають у містах. Виявлено, що найбільше частка українців, які проживають у містах, зростала на півночі країни та в Мінську. Це пов’язано з пошуком роботи та навчанням, тому осередками притягання є обласні центри та столиця країни, рідше - районні центри. В контексті дослідження етнічного складу з'ясовано, що Білорусь - моноетнічна країна, імовірність того, що у двох випадково обраних людей буде різна етнічна належність у більшості районів не перевищує $30 \%$. У процесі дослідження етномовних критеріїв перепису (рідна мова та мова, якою розмовляють удома) виявлено, що відбуваються значні асиміляційні процеси в середовищі української діаспори. Передусім це втілюється в тому, що частка українців, які вважають українську мову рідною, зменшується, натомість позиції російської мови як рідної та мови домашнього спілкування лише посилюються. Також 
встановлено відмінності щодо етномовних критеріїв за статтю та територією проживання. Зокрема українську рідною мовою частіше називають жінки, а українці, які проживають у містах, $є$ більш русифікованими порівняно із сільськими жителями.

Ключові слова: українська діаспора, перепис населення, розселення, національність, асиміляиія, етномовні прочеси.

\section{Introduction.}

The Ukrainian Diaspora - as a phenomenon and integral part of the Ukrainian population - began emerging in the late XIX century when the first migrants from Ukraine started to seek a better life abroad. Two world wars, emigration because of fear of repression for political views and participation in armed struggle for independence only strengthened the emigration. It has not stopped even following the the declaration of independence, because Ukrainians had to emigrate due to economic problems. These processes have resulted in development of communities of Ukrainian migrants in Italy, Spain, Portugal and other countries. Modern migration of Ukrainians was at first illegal, complicating provision of legal help for them in the countries where they resided. Liberalization of immigration legislation in the recipient countries for Ukrainians has brought Ukrainian guest workers out of the shadows and provided them with legal status.

Communities of Ukrainian guest workers are beginning to transfer from marginal groups to diaspora. They obtained legal status and started receiving working or residency permits in the countries where they were staying, and soon afterwards - official employment. Those steps have increased the protection of their access to social services: legal and medical help, paid vacation, insurance of health and life, possibility of receiving pensions in the future.

Some Ukrainians became a diaspora as a result of ill-conceived processes of border division, when political interests of countries led to some ethnic territories of Ukraine being outside the Ukrainian border. Such communities were called "accidental diasporas" by American scientist R. Brubaker, who opposed those communities to labour migrants and "classic' diasporas".

One of the countries with numerous Ukrainian diasporas is Belarus. Despite the factors of a common border and old historical relationships between Ukraine and Belarus, the problems of distribution of Ukrainians in this country have not been studied sufficiently.

As a result of the processes of division between the countries which came about in the XX century, modern-day Belarus includes Berestia (currently Brest Oblast), which was incorporated into the country after a number of territories had been assigned to the Russian Federation. The issue of the Ukraine-Belarus border in the southwest and south parts of the country is still complex and not solved completely.

In view of the autochthonous Ukrainian population in Belarus, a pertinent question is also whether or not to consider the Ukrainians in this country a diaspora.
To avoid confusion in naming groups of Ukrainians which live in Belarus, hereinafter we shall use term "Ukrainian diaspora" to indicate people who called themselves Ukrainians during the census.

\section{Materials and methods.}

The paper was based on the analyses of censuses of the population carried out in the 2020s round (Results of population census 1999, Results of population census 2009, Results of population census 2019), where, contrary to the tendencies toward decrease in the populations of Ukrainians in all the countries of the former Soviet Union, the number of Ukrainians in Belarus has gradually increased compared with the previous census. Such a tendency led us to analyze the results of the recent census in more detail and determine the factors that could influence this result.

Ethnicity is a characteristic of population which is difficult to measure statistically. This may be explained by the fact that ethnic identification depends on a number of external factors (state policy, prejudice toward certain nationalities, etc). Another aspect of this problem is the fact that ethnic identification is not a priority to many people, they do not think about whether or not they easily can unequivocally identify themselves (this concerns children born in mixed marriages).

Ukrainian sociologist and ethnologist Yevtukh V. B. gives the following definition of this term: ethnicity (Greek ethnos - people, tribe) is a term that indicates qualitative characteristics of a person or a group of people related to their ethnic origin, which manifest in everyday life, culture, behaviour, and mentality in general, confirming their origin and distinguishing them from among others. The term is often used to define an ethnic community, language and culture identity of a group of people (Yevtukh, 2012).

Tools that would be useful for such research are the methods of data analysis which can provide the index of ethnic diversity, indicator of socioethnic density, index of ethnic mosaic, coefficient of ethnic similarity, etc. Using ethnic diversity index (EDI) as a mean of researching racial and ethnic diversity in the USA was proposed by researchers P. Meyer and S. McIntosh. Unlike the indicator of the share of one or the other ethnicity in the population of a certain territory, this index allows a researcher to most efficiently use and interpret the results of censuses. This indicator shows the possibility of two randomly selected people in one city, region or country having different ethnic belongings. 
Methods of estimating this index are based on two fundamental principles of probability theory: first, the likelihood of simultaneous occurrence of two independent events equals the derivative of possibilities of those events: $\mathrm{P}(\mathrm{AB})=\mathrm{P}(\mathrm{A}) * \mathrm{P}(\mathrm{B})$; secondly, the probability that at least one of the two independent events will take place equals the sum of those probabilities: $\mathrm{P}(\mathrm{A}+\mathrm{B})=\mathrm{P}(\mathrm{A})+\mathrm{P}(\mathrm{B})$. That is, based on those principles, the index of ethnic diversity is determined.

The index itself is calculated in several stages. The first is determining the share of each ethnic group in the population of the territory. The second is to the square this share. This parameter characterizes the probability that two randomly selected people would be of the same nationality. The third stage is summing the squared probabilities for each nationality and obtaining the final probability that two randomly selected people are of one and the same nationality.

The last stage is subtracting the previous stage from 1. The obtained parameter will be the probability that two selected people are the representatives of different ethnicities. If this value is multiplied by 100 , integers can be used for convenience of further analysis:

$$
\mathrm{EDI}_{\mathrm{j}}=\left(1-\sum_{i=1}^{E} P_{i j} 2\right) * 100
$$

where $\mathrm{j}$ - region, $\mathrm{i}$ - ethnic group in the region, $\mathrm{E}-$ overall number of ethnic groups in the regions.

Ethnic diversity index (EDI) may vary 0 (ethnically homogenous region) to 100 (complete diversity). Specifically, 0 value means that only one ethnic group is represented in the region, whereas an index equaling 100 may be interpreted as follows: the probability that two randomly selected people will be of the same ethnicity is zero. This index is often used to study the ethnic structure of a population and is usually considered as a statistical characteristic, because the analysis of the dynamics of ethnic groups requires additional estimations. It has to be noted that it is the simplest for estimation, but at the same time the least perfect, and therefore must be used in combination with other indicators.

The simplest statistical method of assessing component and territorial structures of a country's population is estimation and evaluation of absolute values and relative shares of ethno-national groups or groups of population according to mother tongue within the framework of country and regions, and also indices of their quantitative ratios. For this purpose, one may also use more complex indicators, which are based on ratio of specific weight of different subjects of ethnogeographic relations, specifically B. Eckel's index of ethnic mosaic, which is calculated using the following formula:

$$
\mathrm{P}_{\mathrm{j}}=1-\sum_{i=1}^{k}(\pi)^{2}
$$

where $\mathrm{P}_{j}$ - index of ethnic mosaic, $\pi$ - share of $\mathrm{j}$ ethnic group in the region's population, $\mathrm{k}$ - number of ethnic groups.

The advantage of Eckel's index is its unambiguousness. Every settlement and administrative unit has a particular value of mosaic index regardless of complexes they are analyzed in. Eckel's index is interesting for comparing whether it is the dynamics of parameter or comparison of separate territories or settlements. It takes into account all ethnicities that live in this territory, but its value is affected only by the most numerous ones. This index is one of modifications of ethnic diversity index.

Similar methodological tasks may be solved using the index of socioethnic density:

$$
\mathrm{I}=\left(\sum_{i=1}^{k} n^{2} / N^{2}\right) * 100,
$$

where I is value of socioethnic density; $\mathrm{n}$ - number of population of an ethnic group in the country (region); $\mathrm{k}$ - number of ethnic groups; $\mathrm{N}$ - overall population of country (region).

Unlike the index of ethnic diversity that estimates the probability of contacts and takes into account relative indicators, the absolute indicators are used to estimate the indicator of socioethnic density. The closer this indicator is to 100 , the more ethnically homogenous is the researched territory. This indicator of socioeconomic density is more useful than using the share of one or another ethnicity in the population, because it takes into account the number of other ethnicities and population of the entire country.

To study the compactness of distribution of ethno-national communities and groups, especially minorities, it would be efficient to use the coefficient of ethnic similarity which was proposed by Y. Lipiets:

$$
\mathrm{K}=\mathrm{K}_{1} * \mathrm{~K}_{2} \text {, }
$$

where $\mathrm{K}_{1}$ is share of population of a certain ethnic group in the population of the entire region; $\mathrm{K}_{2}$ - share of an ethnic group that lives in this region in the total number of this group in the country.

Differentiation of this indicator allows districts to be distinguished with high and low concentrations of the population of an ethnic group (Dnistrjans 'kyj, 2008). Its application in researching the diaspora is more effective than using the share of Ukrainians in the overall population or share of Ukrainians living in the territory of a certain administrative unit in the overall number of Ukrainians in this country. That is, the coefficient of ethnic similarity depends on what share in the population one or the other ethnicity makes and what share of the entire population of this ethnicity is living in the territory.

A clear picture of distribution of Ukrainians in another country may be obtained using the coefficient of 
ethnic compactness $\left(\mathrm{K}_{\mathrm{eK}}\right)$. It complements the shares of Ukrainians in the overall population or share of Ukrainians in a certain region of the overall number of Ukrainians in the country, which we estimated. This coefficient is a modification of the previous formula:

$$
\mathrm{K}_{\mathrm{ec}}=\mathrm{K}_{1} / \mathrm{K}_{2} \text {, }
$$

where $K_{1}$ is the share of a certain ethnicity in a region's population; $\mathrm{K}_{2}$ - share of representatives of this ethnicity in the region's population. If $\mathrm{K}_{\mathrm{ec}} \leq 0.5$ - ethnic compactness is expressed indistinctly; if $0.5<\mathrm{K}_{\mathrm{ec}} \leq 1-$ compactness is expressed quite distinctly; if $1<\mathrm{K}_{\mathrm{ec}} \leq 2-$ ethnic compactness is expressed distinctly.

Using the share of representatives of a certain ethnicity in the region's population, in our opinion, is more practical than using this indicator for a country, because it somewhat alters the ultimate results.

\section{Results and their analysis.}

After declaring independence, three censuses were carried out in the country - in 1999, 2009 and 2019. Belarus is one of the few countries of the former USSR which follows the recommendations of the Eurostat (European Statistical Office) regarding the methods and time of conducting censuses. According to the results, 237,014, 158,723 and 159,656 Ukrainians were living in the country, respectively. Compared with the census of 1999, the number of Ukrainians in 1989 decreased by $18.6 \%$, and in the inter-census period of 1999-2009, this parameter reached 33\% (Results of population census 1999, Results of population census 2009, Results of population census 2019). However, the next period between the censuses, 2009-2019, indicated $0.6 \%$ increase in the Ukrainian diaspora.
The number of Ukrainians among the population of the country has been gradually decreasing since 1999 (according to the results of 1999 census, Ukrainians accounted for $2.36 \%$ of the overall population of Belarus). According to the results of the recent censuses, the share of Ukrainians was 1.67 and $1.7 \%$, respectively. It has to be noted that the population of Belarus decreased from 10.045 M to $9.413 \mathrm{M}$ people over the period from 1999 to 2019.

Despite living in ethnic Ukrainian territories, the share of Ukrainians in the population is stably low, as indicated by the results of censuses carried out in the Soviet Union. According to 1959 census, 133.1 thou Ukrainians were living in the country $(1.6 \%$ of the overall population), 190.8 thou (2.1\%) in 1970, 231 thou $(2.4 \%)$ in 1979, 291 thou (2.9\%) in 1989 (Zubyk, 2019).

That is, according to the most recent census, performed in 2019, the number of Ukrainians and their share in the population are similar to such of 1959. The population of Belarus in 1959 was $8.055 \mathrm{M}$ people. Over the 60 years that passed between the censuses of 1959 and 2019, the country's population increased by 1.358 $\mathrm{M}$ people in absolute values, the number of Ukrainians - by 26.5 thou people. Taking into account the long period between those censuses, such an increase is insignificant. According to the results of the recent census, Ukrainians are the fourth ethnic group by number, after Belarusians, Russians and Poles (Ethnic composition...to the 1999 census, Ethnic composition...to the 2009 census, Ethnic composition...to the 2019 census). Ukrainians mostly live in Brest and Gomel Oblasts and Minsk, comprising $61 \%$ of all Ukrainians in the country (according to 2009 census, this parameter equaled 62\%) (Fig. 1-3).

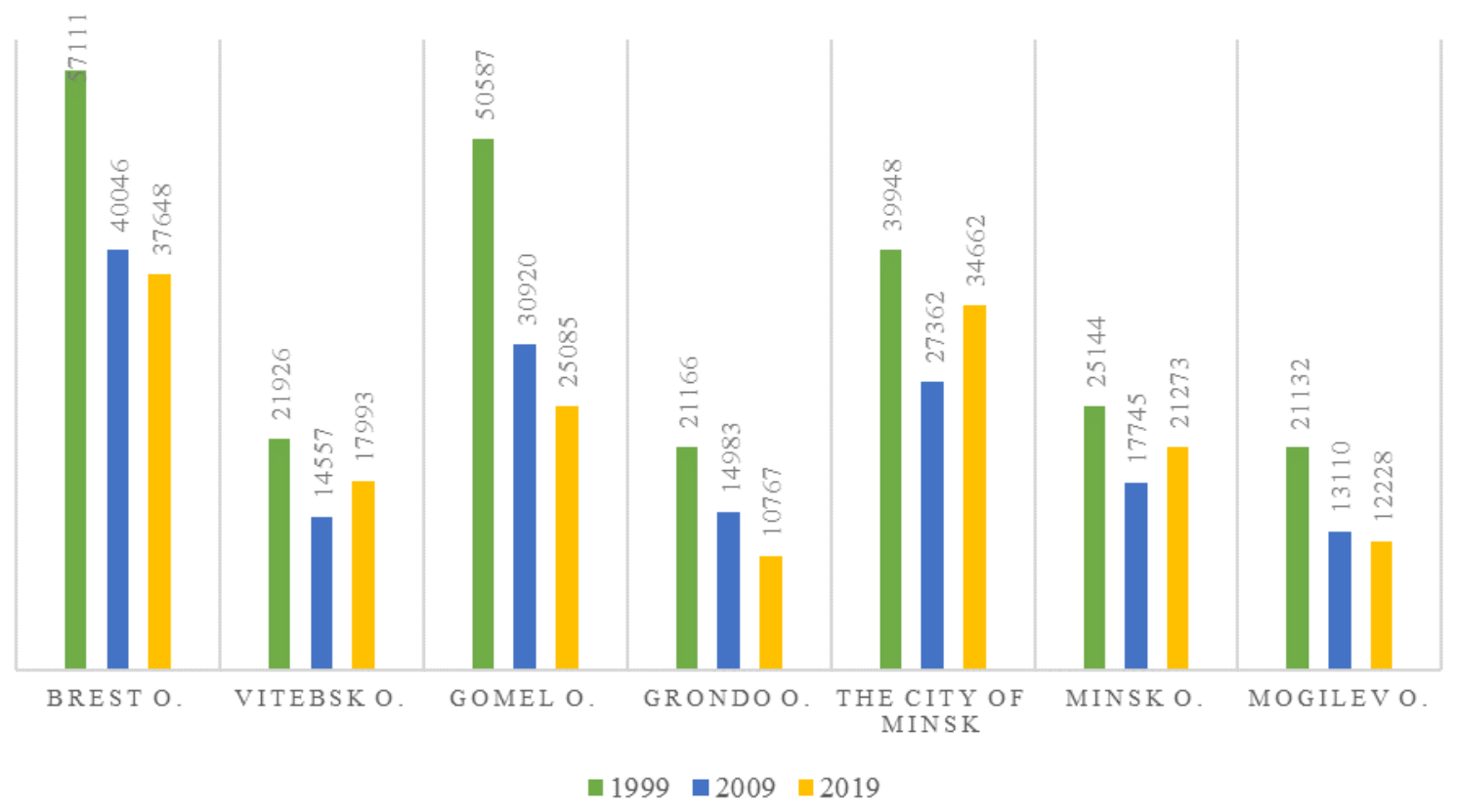

Fig. 1. Distribution of Ukrainians in the oblasts of Belarus according to the censuses of 1999, 2009, and 2019. 
The areas of dense concentrations of Ukrainians are the southwest part of the country (districts of Brest Oblast which border with Ukraine), a strip of districts between cities of Minsk and Gomel with ramification to cities of Salihorsk and Mazyr. Also, there are concentrations of Ukrainians in the cities of Grodno, Lida, Barysaw, Vitebsk, Orsha and Polotsk, which are the centers of districts of the same names, where numbers of Ukrainians are large as well. In the largest cities - Brest, Baranovichy, Pinsk, Vitebsk, Novopolotsk, Orsha, Polotsk, Gomel, Grodno, Mogilev, Babbruysk and Minsk - 83,376 Ukrainians live, accounting for 68\% of the overall number of Ukrainians who live in cities. According to the 2019 census, 90,418 Ukrainians were living in 11 cities, i.e. $72.5 \%$ of the overall Ukrainian population in cities (Zubyk, 2019).

According to the 2009 census, the urbanization of the Ukrainian diaspora was $77.2 \%$ (78.1\% in 2019). In 51 districts, majority of the Ukrainians were living in villages, particularly 12 of 16 districts of Brest Oblast (12), 15 of 21 districts of Vitebsk (13), 7 of 21 districts of Gomel (7), 9 of 17 districts of Grodno (9), 7 of 22 districts of Minsk (12) and 8 of 21 districts of Mogilev oblasts (8), where $64.3 \%$ of the overall number of the Ukrainian rural population was living ( $a c$ cording to the 2009 census).

Brest and Minsk oblasts qualitatively differ among the structures of the oblasts. In Brest Oblast, Ukrainians live in ethnic Ukrainian lands. The lowest level of urbanization of Ukrainians in Minsk Oblast is explained by the fact that most Ukrainians live in Minsk, which as the capital attracts people not only from the Oblast but from the whole country. Application of the similarity factor to Minsk or any other large city of the country shows that people prefer travelling to these places for study, work, services, etc.

Compared with the results of the 2009 census, the urbanization level manifested to a different extent across the districts. Increase in the share of Ukrainians living in cities was observed in the north of the country. In Brest Oblast and districts that border with Ukraine, the share of the Ukrainian urban population decreased. Across the largest cities of the country, the number of Ukrainians increased in Novopolotsk $(+77.45 \%$ compared with 2009), Polotsk (+53.8), Orsha $(+42.2)$, Zhodzina (+39.4), Minsk (+26.7), Vitebsk (+26), Brest $(+16)$ and Mogilev (+7). The Ukrainian populations decreased in the cities Baranovichy (-10.1\%), Babbruysk (-11.6), Pinsk (-11.9), Gomel (-22.4) and Grodno (-32.9) (Fig. 4).

Large oblast centers and the capital remain the centers of attraction for Ukrainians: Minsk, Vitebsk, Polotsk, Novopolotsk, Orsha. In ethnic territories and the Belarus-Ukraine border, such a city is Brest - the oblast center and the heart of the ethnic Ukrainian territory.

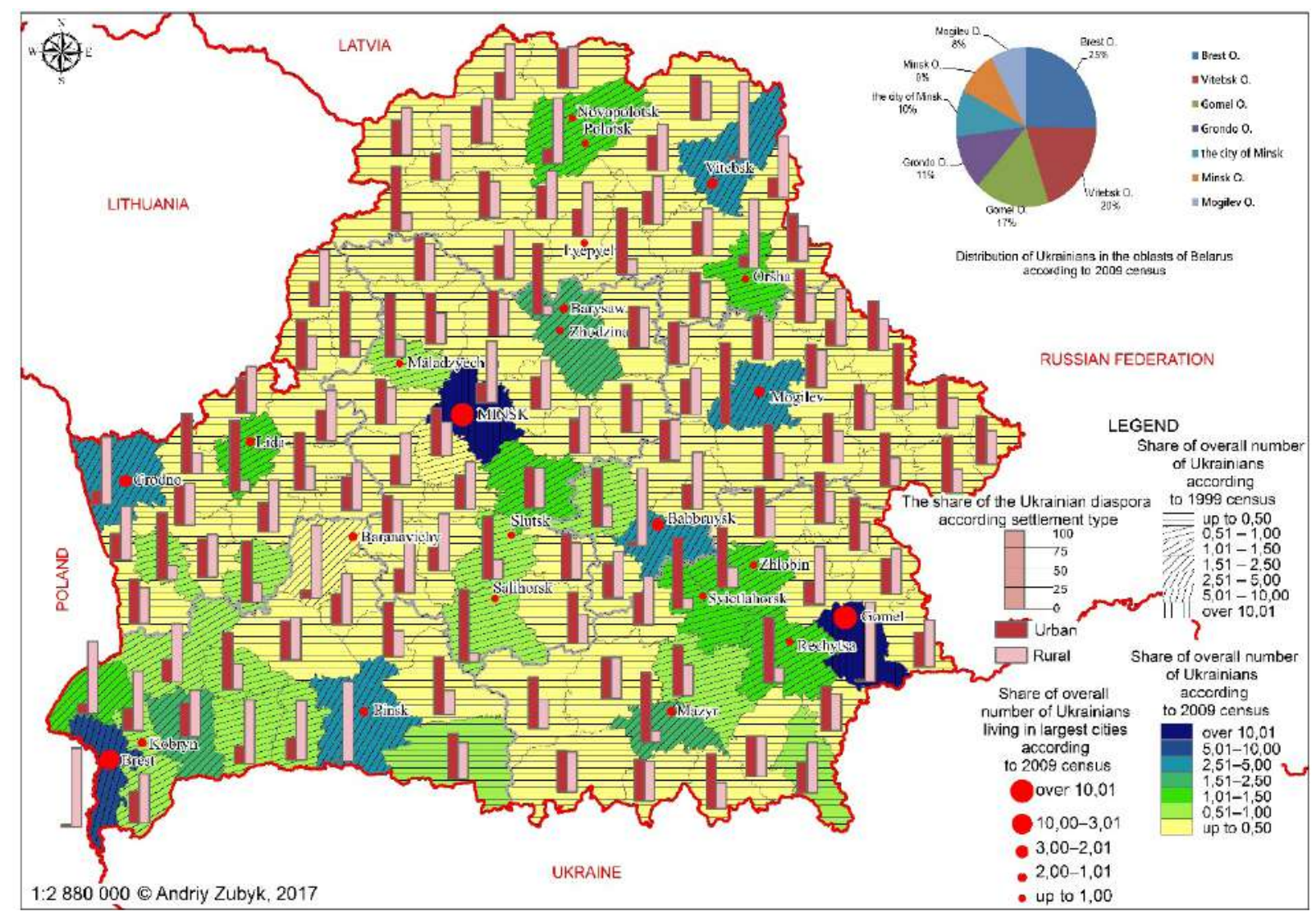

Fig. 2. Distribution of Ukrainians in districts of Belarus according to the censuses of 1999 and 2009 (Zubyk, 2019). 


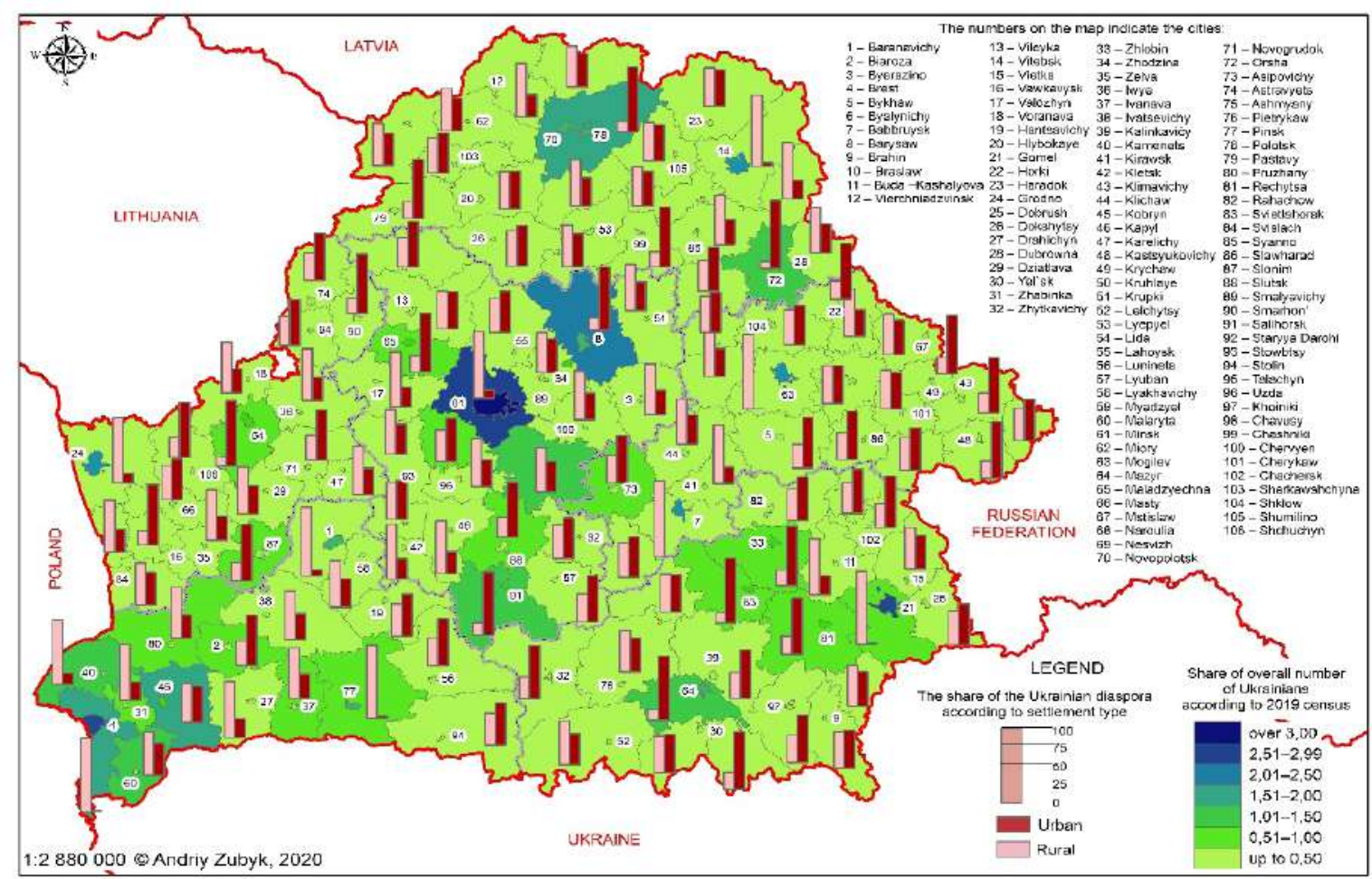

Fig. 3. Distribution of Ukrainians in districts of Belarus according to the 2019 census.

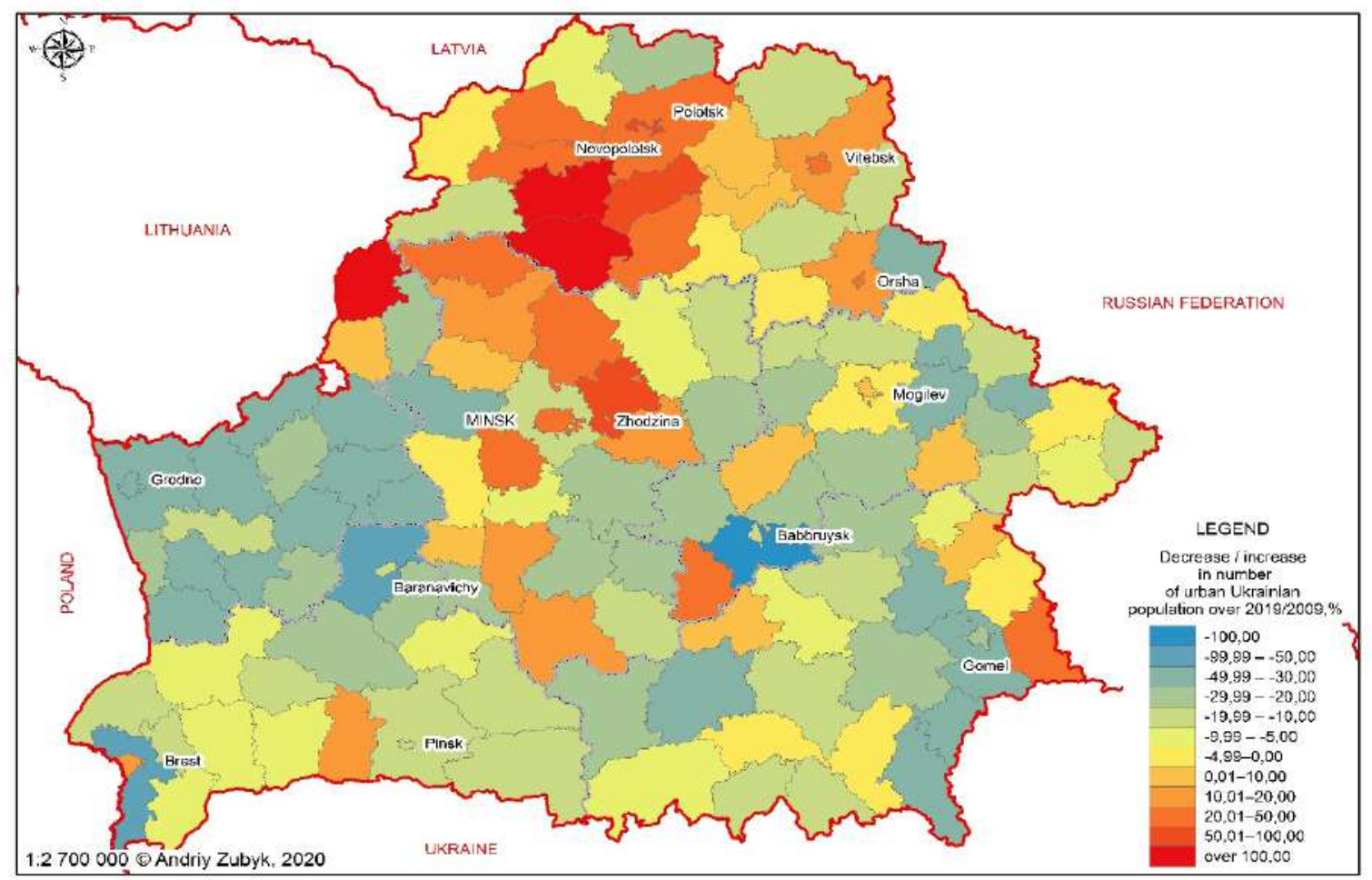

Fig. 4. Change in the share of the urban Ukrainian population in districts and the largest cities of Belarus according to the censuses of 2009 and 2019.

Ukrainians living in the oblasts that include eth- the territories that are influenced by the Belarusian lannic Ukrainian lands within Belarus, and distribution of guage, as well as weak integration into Ukrainian culUkrainians and territories of Gomel Oblast which border Ukraine. Ukrainians are autochtonous inhabitants of Brest Oblast. The specifics of life of Ukrainians in tural and political life, have caused insignificant level of Ukrainian self-awareness. After Beresteishyna and Pinshchyna had been incorporated into the Belarus SSR, 
the Ukrainians began to be identified as Belarusians in legal documents (Dnistrjans'kyj, 2008).

If in $2009,25.2 \%$ of the country's overall Ukrainian population were living in Brest Oblast, in 2019, this figure had fallen to 23.6. The share of Ukrainians in the population according to the 2019 census was $2.79 \%$, whereas in the previous period it was $2.86 \%$. Over a half of Ukrainians of Brest Oblast (53.1\%) were living in cities of Brest, Baranovichy and Pinsk, as compared with $46.3 \%$ according to the 2009 census.

Across the districts, the share of Ukrainians decreases from southwest to northeast, i.e. the further from Belarus-Ukrainian border, the lower the number of Ukrainians . By share of Ukrainians in the population, districts of Brest Oblast may be conditionally divided into 5 groups: 1 . Brest, Kamenets, Malaryta districts (share of Ukrainians in the population equals over $5 \%$, i.e. on average each $20^{\text {th }}$ resident in those districts identifies him or herself as Ukrainian); 2. Zhabinka, Kobryn and Pruzhany districts (share of Ukrainians in the population equals 2.51 to $5 \%$ ); 3 . Drahichyn, Ivanava, Pinsk and Stolin districts (2 to 2.5\%); 4 . Berezivka district (1.67\%); 5. Baranavichy, Ivatsevichy, Lyakhavichy, Hantsavichy, Luninets (up to $1 \%$, i.e. less than one in a hundred considers him or herself as Ukrainian).

Across the largest cities of the Oblast - Brest, Baranavichy and Pinska - shares of Ukrainians in the populations equal $4.41,1.37$ and $2.09 \%$ respectively. While the shares of Ukrainians in the entire populations of Pinsk and Pinsk district are approximately the same -2.09 and $2.12 \%$ respectively, the parameters for Brest and Baranavichy vary. The smaller share of Ukrainians in Brest, compared with Brest District, may be explained by the fact that, as the Oblast center, Brest has a more diverse ethnic composition, a larger population. Instead, Baranavichy as a district center attracts population from the villages.

Tempos of decrease in the number of Ukrainians in Brest Oblast were not as intense as in the rest of the country, though the number of Ukrainians decreased almost by a third (29.9\%) over 1999-2009. In most districts of the oblast, the decline in the Ukrainian population was lower than the average decrease across the country. The share of the Ukrainian rural population in Brest Oblast is almost twice larger than the average value in the country -40.2 and $22.8 \%$ respectively.

Over the period between the censuses of 2009 and 2019, the number of Ukrainians living in Brest Oblast decreased by $6 \%$. Compared with the previous period, the tempos of decrease in the Ukrainian population have slowed by 5 times. In a number of districts, the dynamics of decrease in the Ukrainian population corresponded to the tendency across the country or was better. Over 2009-2019, the share of Ukrainians living in cities increased: $67.8 \%$ compared with 59.8 in 2009. Increase in the share of the urban Ukrainian population in the oblast is associated with the cities Brest, Baranovichy and Pinsk. Across the districts of the oblast, there are 3 of 16 where most Ukrainians live in cities: Berezivka, Luninets and Stolin.

Of all the districts and cities of Brest Oblast, the positive dynamics of increase in the Ukrainian population was seen in Hantsavichy district and Brest. The absolute changes in the population of Ukrainians over 2009-2019 ranged +2,059 Ukrainians (city of Brest) to -804 Ukrainian (Kamenets district). The relative values for this same period ranged $+16 \%$ (city of Brest) to -20 (Kobryn district), -22 (Lyakhavichy district), -28 (Kamenets district), -30.9 (Pinsk district) and -46.1 (Baranovichy) (Fig. 5).

Ukraine borders with Lyelchytsy, Yel'sk, Naroulia, Khoiniki, Brahin, Loyew, Gomel and Dobrush districts of Gomel Oblast. According to the 2009 census, 4,513 Ukrainians were living ( $14.6 \%$ of the overall number of Ukrainians who were living in the Oblast) in those districts. Relative changes in the number of Ukrainians in those territories over the period of 1999 2009 ranged $-32.42 \%$ (Naraulianski district) to $-65.6 \%$ (Brahinski district).

In 2019, 3,261 Ukrainians were living in those territories (13\%). Over 2009-2019, the absolute values of Ukrainians decreased by 1,252 people, relative values - by $-27 \%$. While the city of Brest is a "magnet" that attracts Ukrainians from the oblast, in 2009-2019, the Ukrainian population in Gomel and cities of the oblast became smaller (see Fig. 4). Ukrainians live in villages, the share of rural Ukrainian population is three times larger than in the oblast on average (Results of population census 1999, Results of population census 2009, Results of population census 2019).

The analysis of decrease in the number of Ukrainians in districts and the largest cities (Fig. 6-7) suggests that the lowest values were observed in the ethnic Ukrainian territories, partly fewer relative changes in the number of Ukrainians were determined for the districts that border with Ukraine. Such processes may be explained by the fact that the level of urbanization of Ukrainians in Brest Oblast is lower than the average parameter for the country. Living in rural areas somewhat slows the processes of ethnic assimilation, unlike life in the cities, where ethnic compositions are more diverse.

Decrease in the Ukrainian population in the largest cities is lower compared with the mean parameter for the country. The cities face internal migration due to education, search for work, etc. A bright example is the city of Minsk. In districts that border with the capital, the tempos of decrease in population of Ukrainians over the inter-census period of 2009-2019 between the censuses were also lower. 


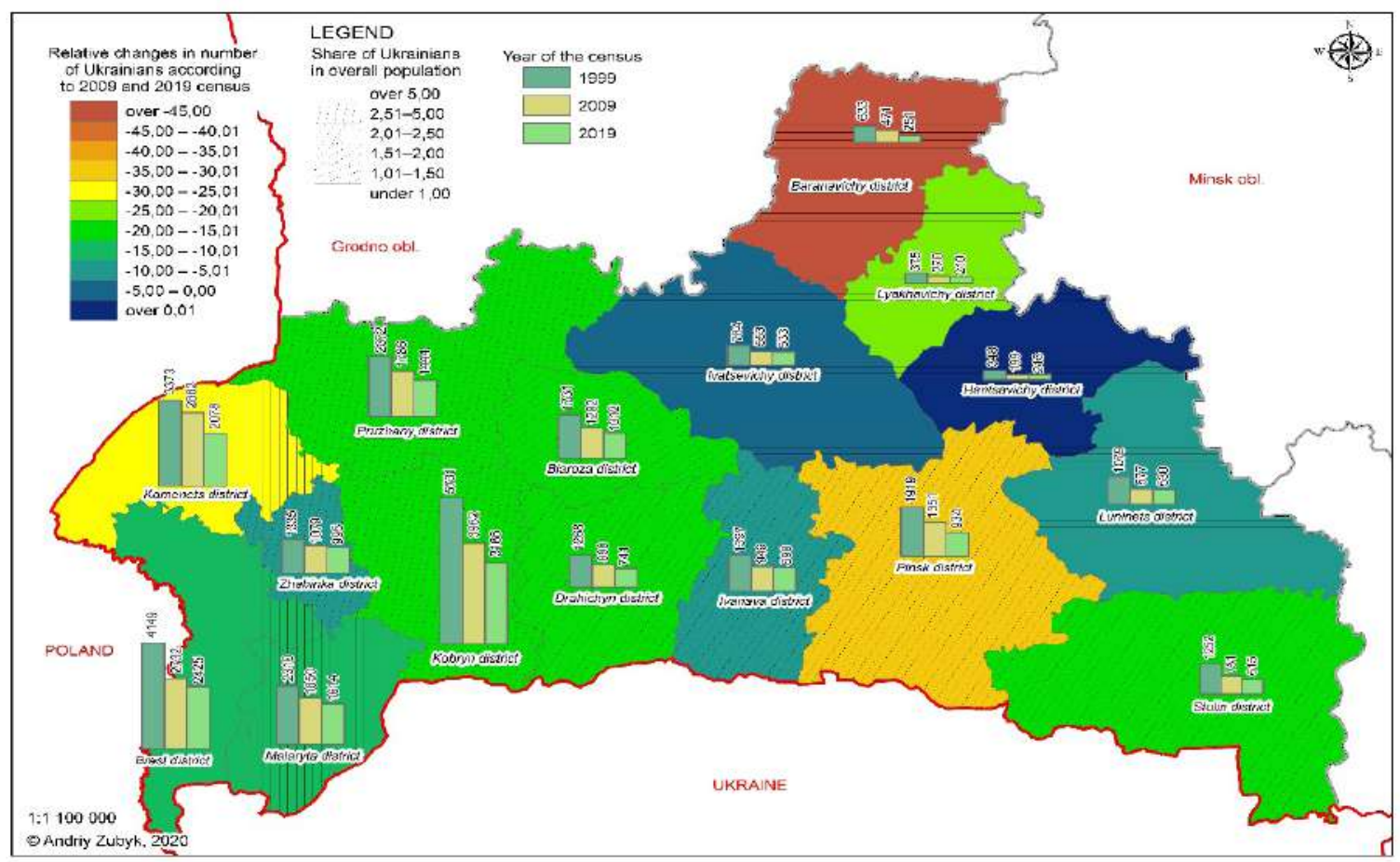

Fig. 5. Number and relative changes in the distribution of Ukrainians in the districts of Brest Oblast according to 2009 and 2019 censuses.

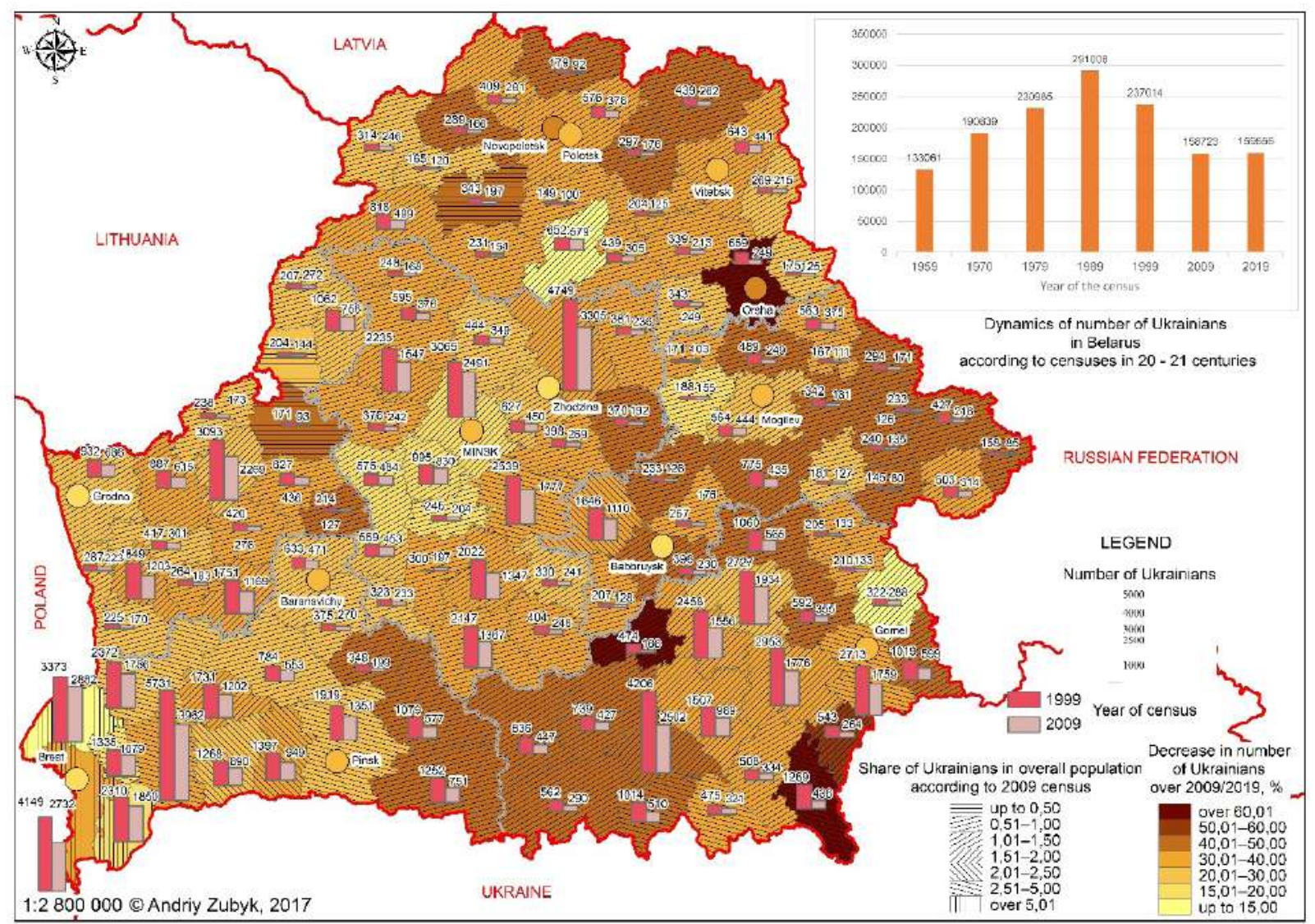

Fig. 6. Number and relative changes in number of Ukrainians in districts of Belarus according to 1999 and 2009 censuses (Zubyk, 2019) 


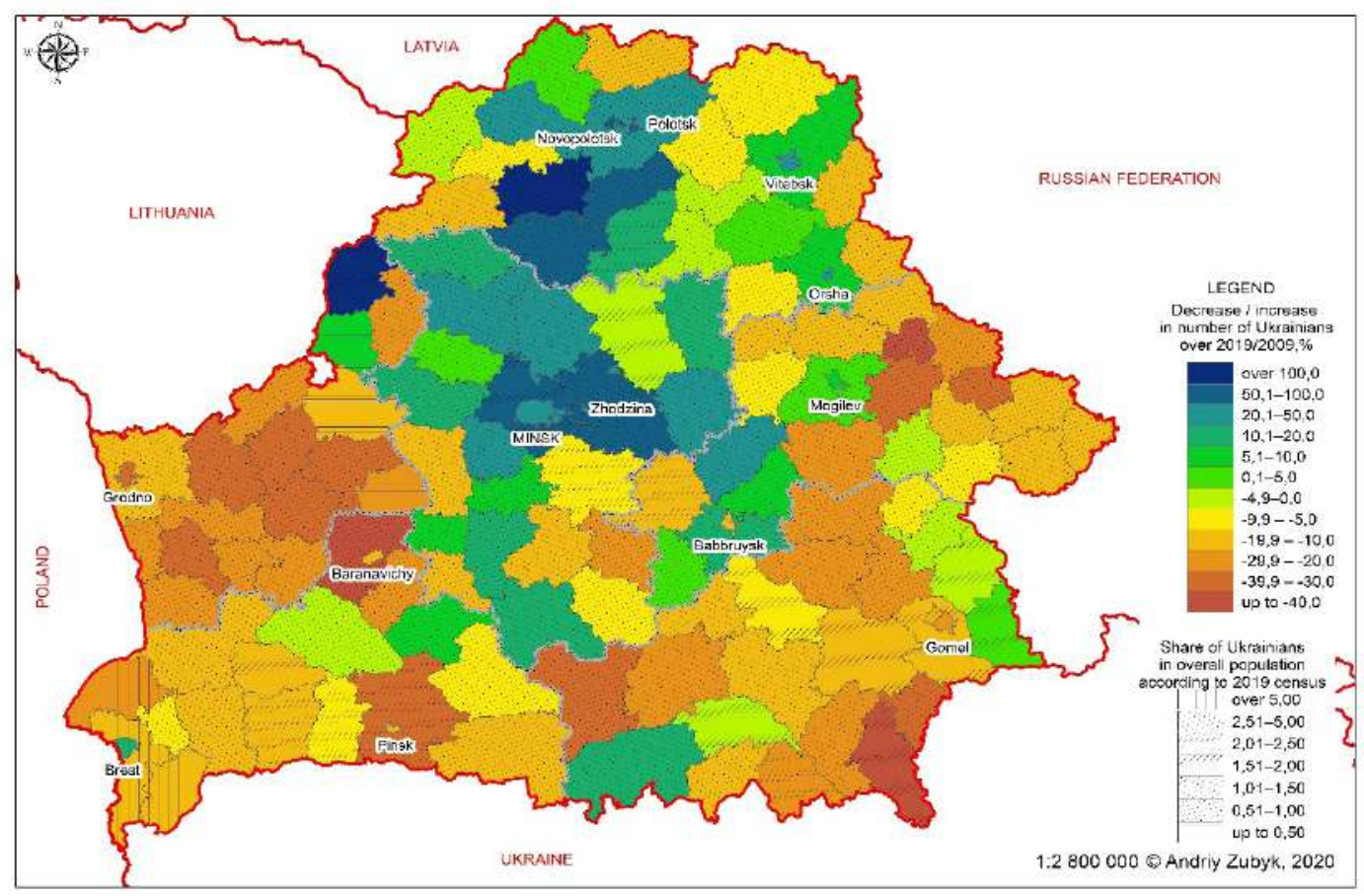

Fig. 7. Share of Ukrainians in population and relative changes in number of Ukrainians in districts according to 2009 and 2019 censuses.

As indicated in Fig. 7, more relative changes in the number of Ukrainians occur in the center and in the north of Belarus, particularly the strip of districts between the capital and cities Novopolotsk and Polotsk with ramification toward Mogilev. The strip comprises Dzyarzhynsk, Valozhyn, Maladzyechna, Vileyka, Lahoysk, Smalyavichy, Minsk, Chervyen, Klichaw, Byerazino and other districts. In this group, the share of Ukrainians living in cities increased (see Fig. 4). During the period between the 2009 and 2019 censuses, the greatest relative changes in the population of Ukrainians were determined across the entire Grodno oblast; though taking place more slowly, the number of Ukrainians living in ethnic Ukrainian territories and in the BelarusUkraine border zone has been decreasing.

Despite the insignificant increase in the number of Ukrainians in several districts of Gomel Oblast, districts near the Belarus-Russia border were observed to have negative tendencies in the dynamics of Ukrainians. In the context of relative changes in the size of the Ukrainian population over 2009-2019, we can state that Ukrainians move out of border, oftentimes poorly developed, districts to the center of the country, to which the location of the capital contributes.

It should be noted that determining the share of Ukrainians in the overall population, share of Ukrainians who live in a certain district or city in the overall number of Ukrainians in the country, analysis of absolute and relative values and their number during the period between the censuses do not provide objective under- standing of such a complex notion as ethnic assimilation and its influence on the ethnic population in the future.

For detailed analysis of ethnic composition of the country's population, we calculated several mathematical-statistical parameters, namely: index of ethnic diversity, index of socioethnic density, coefficients of ethnic community and ethnic compactness in the largest cities and districts. The first two parameters were determined for five nationalities: Belarusians, Russians, Poles, Ukrainians and other. Such an approach was chosen because of the significant quantitative difference between the four most numerous ethnicities, therefore the remaining ethnicities were identified to the "other" category.

Fig. 8 demonstrates that Belarus is a monoethnic country, and the probability that both of two randomly chosen people would have different ethnicity is quite low - in the majority of districts it does not exceed 30\%. Ethnic diversity of the population of the country's largest cities does not exceed the mean value for the country. Large cities and the capital should be "magnets" attracting not only representatives of the titular ethnicity, but also the representatives of ethnic minorities. Most border districts are not ethnically diverse. In most of those districts, Belarusians dominate in the structure of the population. Also, such parameters may be explained by the prevalence of the rural population, whereas representatives of ethnic minorities are more "urbanized" compared with the titular ethnicity, except for the au- 


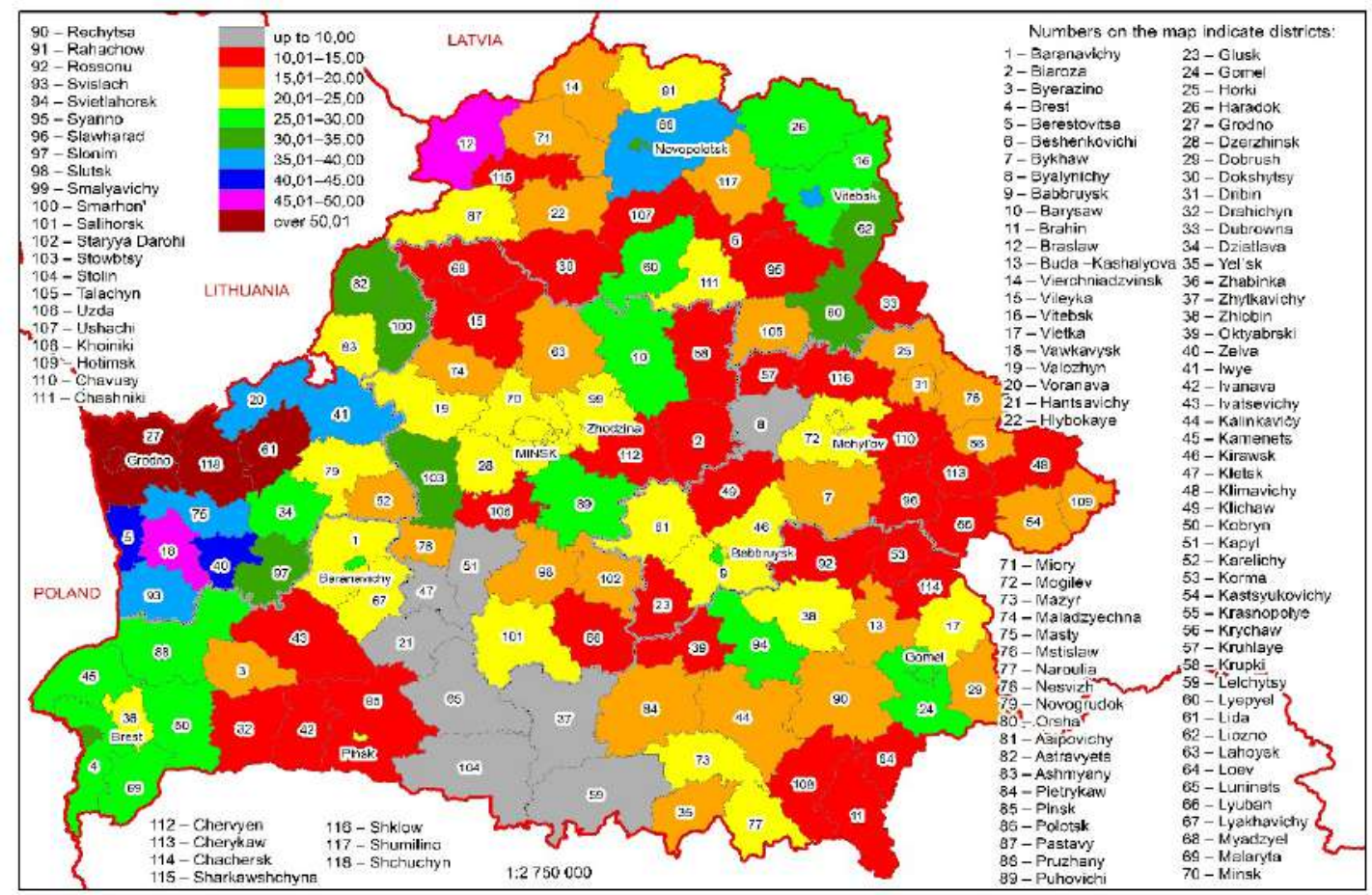

Fig. 8. Index of ethnic diversity in districts of Belarus according to the results of 2019 census.

tochtonous population that prefers living in its own ethnic territory (for example, Ukrainians in Brest Oblast).

Across the largest Belarusian cities, the most diverse ethnic composition is in Grodno. The parameter of ethnic diversity in this city means that the probability of different ethnicities of two randomly selected people in Grodno equals over 50\%.

The highest index of ethnic diversity was determined for districts of Grodno Oblast (Grodno, Lida and Shchuchyn districts); such parameters may be explained by the border with Poland and Lithuania and higher share of Poles in the district's population compared with the rest of the districts. The most ethnically diverse districts of Belarus are in the southwest part of the country (already mentioned districts of Grodno Oblast and some districts of Brest Oblast). In the rest of the country's territory, the index of ethnic diversity does not exceed $20 \%$. An eloquent example is decrease in the value of ethnic diversity in Brest Oblast oriented "west-east", i.e. the following is seen: lower share of Ukrainians in the population means lower parameter of ethnic diversity. Greater ethnic diversity oftentimes is related to the factor of oblast center or district center, for example the city of Gomel and the district of the same name, Novopolotsk and Polotsk district, Vitebsk and Vitebsk district.

Calculation of the socioethnic density index also confirmed that Belarus is a monoethnic country; in most districts and large cities, this parameter is higher than
70 (the closer the parameter is to 100 , the more ethnically homogenous is the territory). As with previous parameter, lower socioethnic density is seen in some districts of Brest and Grodno Oblasts and large cities of the country. This is because Ukrainians and Poles densely live there, while ethnic composition in large cities is more diverse compared with rural areas, - this affects the value of this parameter. Having determined this parameter, we can see that the country's territory is actually homogenous in its ethnic composition (Fig. 9).

Dense inhabitation in the ethnic Ukrainian territories and large cities of the country led to comparatively low coefficient of ethnic similarity in most regions (Fig. 10). This is also due to the insignificant presence of Ukrainians, which had contributed to their share in the overall population, and larger population in a district or city. Another factor this parameter depends upon is the presence of one or several centers where a large part of representatives of one ethnicity lives (for example, autochthonous population, attraction of migrants to labour markets, etc). The highest values of this parameter were determined in the ethnic Ukrainian territories (Brest, Kamenets, Kobryn, Malaryta districts and the city of Brest). Also, this category includes the capital and Minsk district, cities Gomel and Zhodzina. In the majority of territories with high coefficient of ethnic similarity, this fact is explained by attraction of population to large cities or oblast centers. 


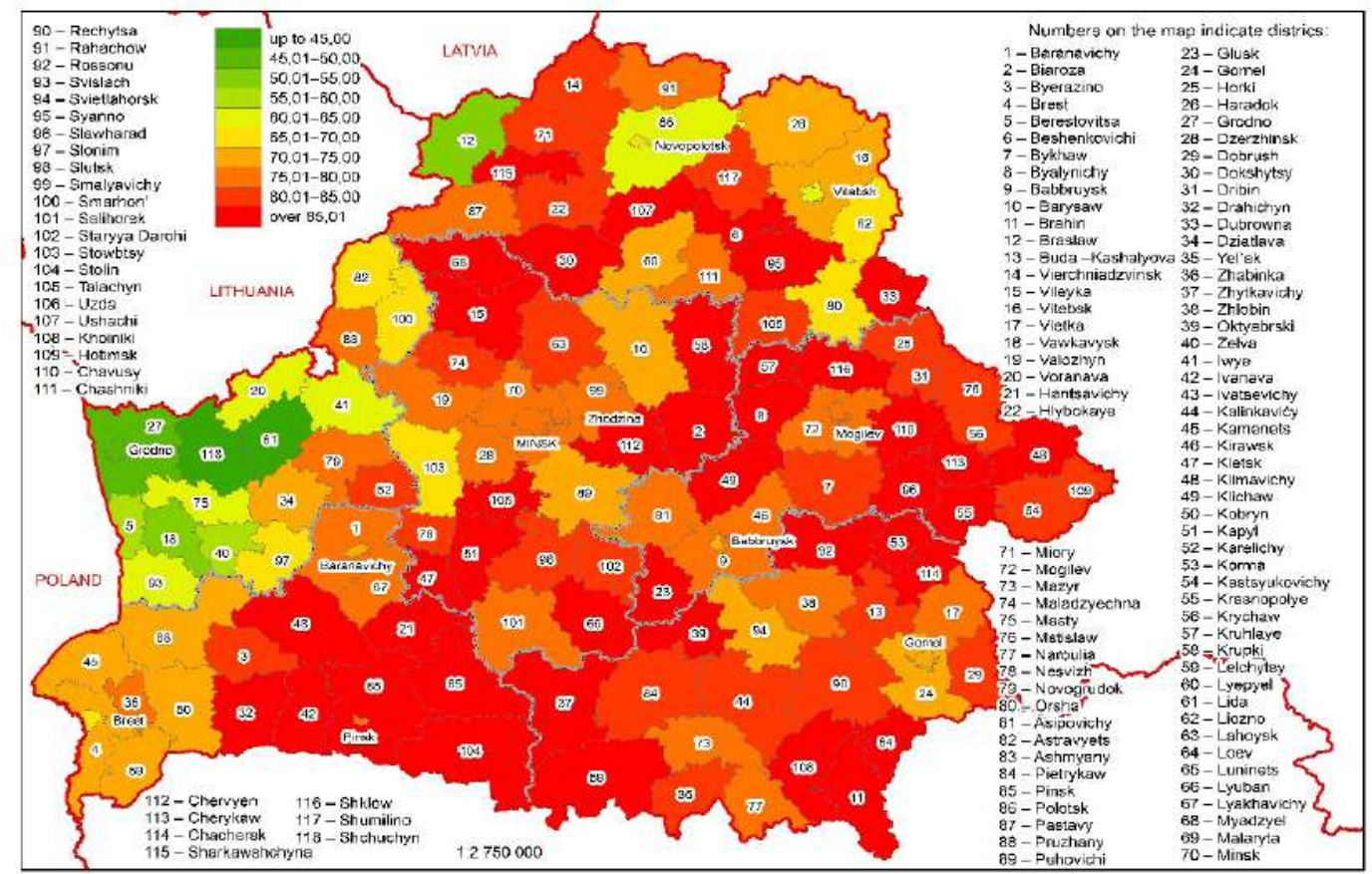

Fig. 9. Parameter of socio-ethnic density in districts of Belarus according to 2019 census.

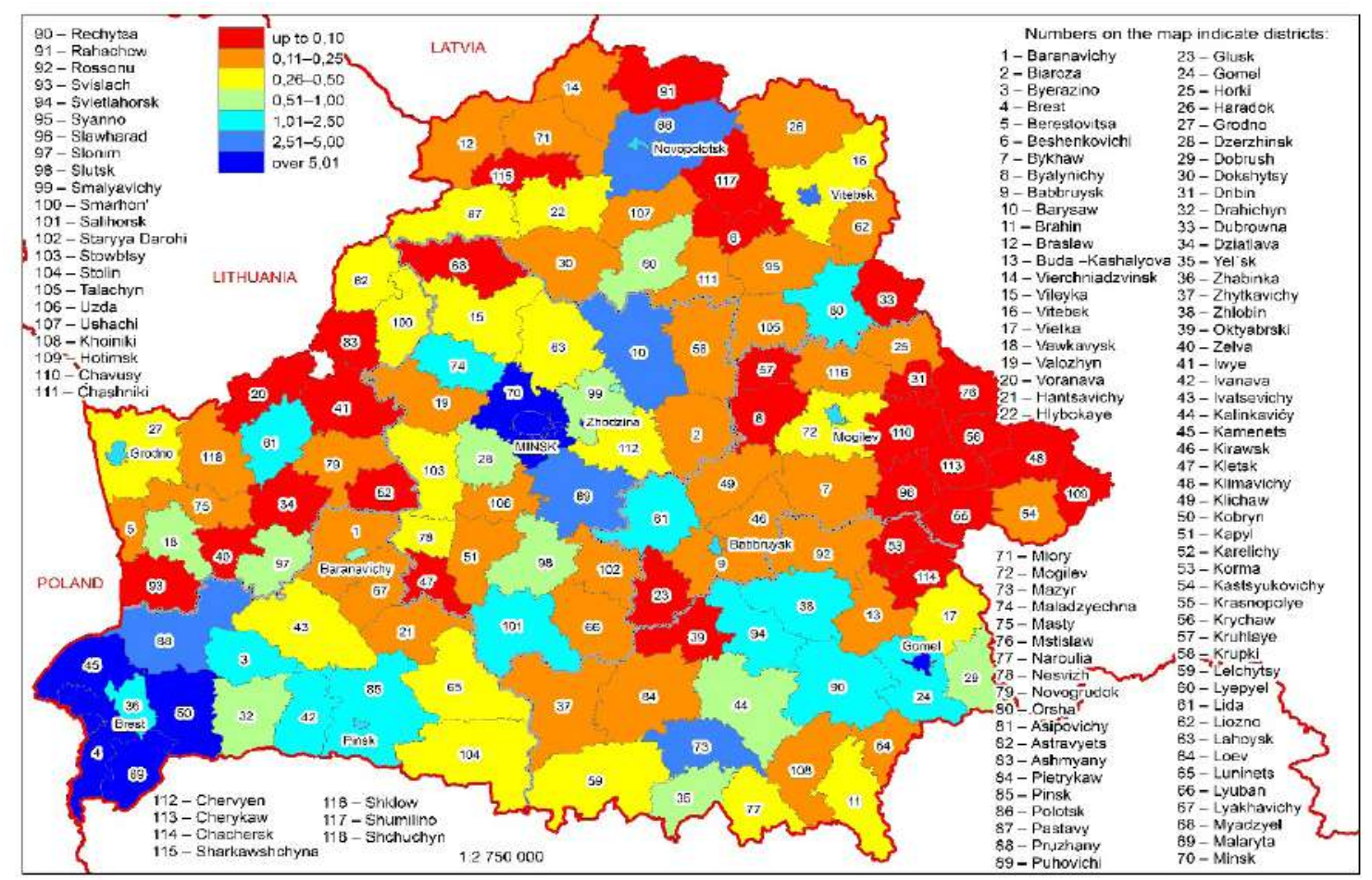

Fig. 10. Coefficient of ethnic similarity in districts of Belarus according to results of 2019 census. 


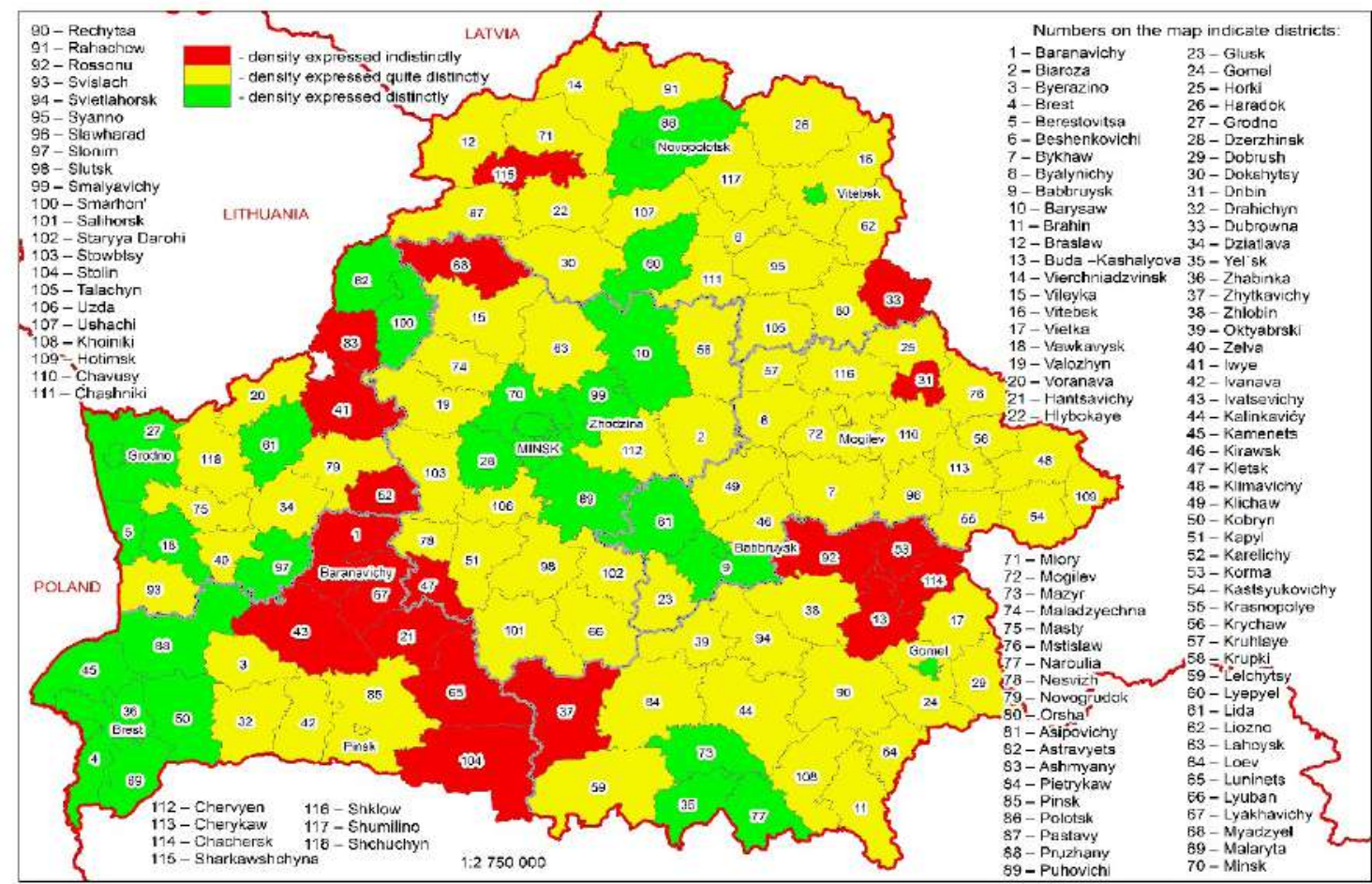

Fig. 11. Coefficient of ethnic compactness of Ukrainians in districts of Belarus according to results of 2019 census.

According to the coefficient of ethnic density which we obtained for districts and large cities, we determined that most of districts are characterized by correspondence of share of Ukrainians in the district population to share of Ukrainians in the Oblast population. In many districts of the country, ethnic density of Ukrainians is quite distinct (Fig. 11). This parameter is best expressed in the ethnic Ukrainians territories and large cities of Belarus. Also, to this category, we can classify districts around the closest cities and several border districts.

Among the ethnolinguistic parameters that are being collected during the censuses of the Belarus popu- lation, there are mother tongue and the language the respondent speaks at home (home language). According to the 1989 census, ethnolinguistic correspondence of Ukrainians accounted for $45.4 \%$, whereas $48.7 \%$ named the Russian language as their native tongue. The language of the titular ethnicity was named by $5.9 \%$ of all Ukrainians. The highest ethnolinguistic correspondence of Ukrainians was in Brest Oblast - 55.6\% of the overall population of Ukrainians named Ukrainian as their mother tongue (Fig. 12) (Zubyk, 2019).

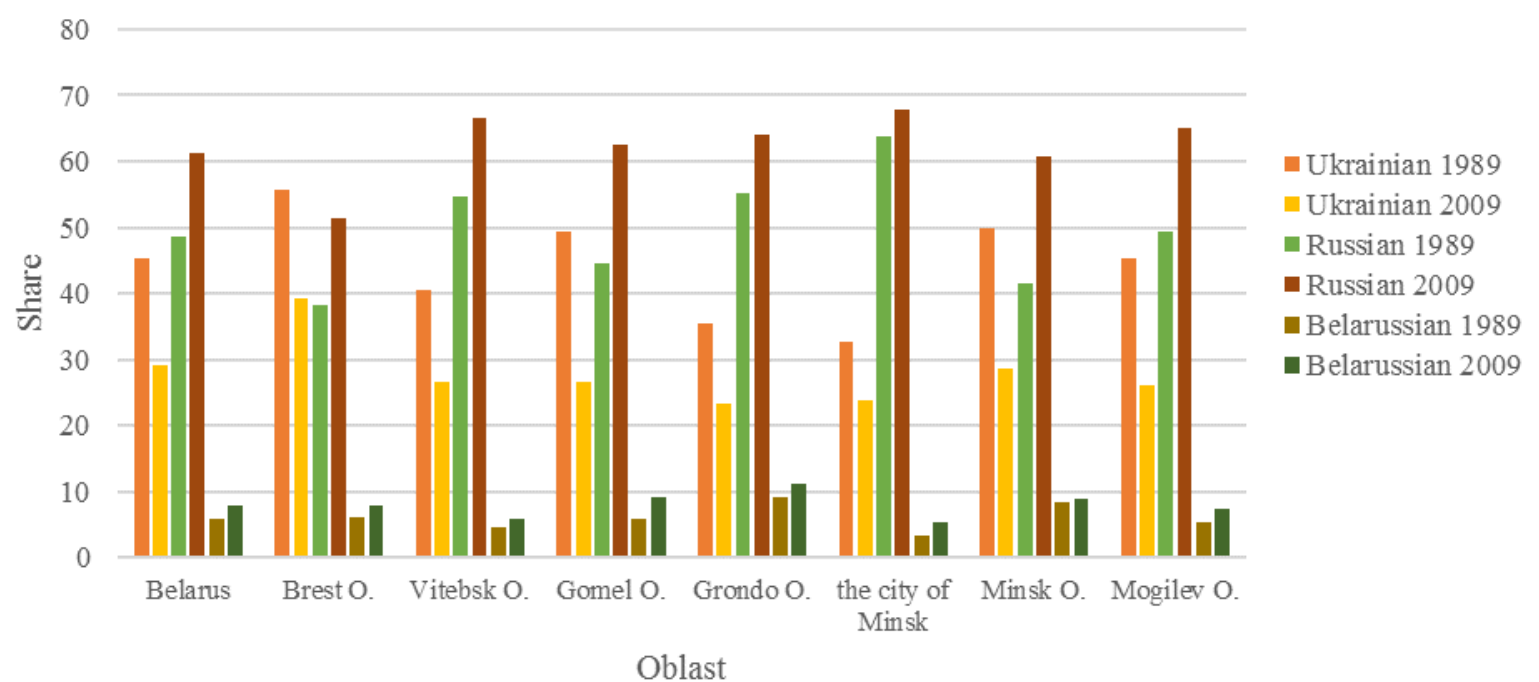

Fig. 12. Ethnolinguistic correspondence of Ukrainians in oblasts of Belarus according to 1989 and 2009 censuses. 
At the time of writing this, the Statistical Committee of Republic of Belarus has not presented the data on ethnolinguistic criteria of the 2019 census for the Oblasts. The research is also complicated by the fact that no results of ethnolinguistic criteria of censuses are available for districts.

As we see in Fig 12, during 1989-2009, language assimilation of Ukrainians occurred. First of all, this meant decrease in the share of Ukrainians who considered the Ukrainian language their mother tongue, $--16.2 \%$ across the country. By oblasts, changes in the share vary $-9 \%$ (city of Minsk) to $-22.8 \%$ (Gomel Oblast). As a result of mixed marriages and ethnic assimilation, Ukrainians in Belarus become Russianized over 1989-2009, the share of Ukrainians that consider the Russian language as their own increased by $12.5 \%$. Across the oblasts, Russianization had the greatest impact on Ukrainians who live in Minsk Oblast - compared with the 1989 census, the share of Ukrainians who consider the Russian language their mother tongue increased by $19.3 \%$. The language of the titular nation was considered mother tongue by $2.05 \%$ more Ukrainians than during 1989 census. This parameter has increased the most in Gomel Oblast $-3.2 \%$.

According to the results of the 1999 census, Ukrainian was named as mother tongue by $42.9 \%$ of the Ukrainians, Belarusian - by $14.3 \%$ and 42.8 namedthe Russian language as their mother tongue. Languages spoken at home were Russian $-83.6 \%$, Belarusian 10.2 and other $-6.2 \%$ (Tables $1-2$ ).

In 2009, Ukrainian was mother tongue for almost every third Ukrainian (29.3\%). The highest parameter of ethnic language correspondence of Ukrainians was in Brest oblast (39.3\%), in the remaining oblasts
$-23.4 \%$ (Grodno oblast) to $28.7 \%$ (Minsk oblast). The Russian language was considered mother tongue by $61.2 \%$ of Ukrainians, the highest this parameter being in Minsk $-67.9 \%$, the lowest - in Brest Oblast (51.9\%). Belarusian was considered mother tongue by $7.9 \%$ of Ukrainians. This parameter was the highest in Grodno Oblast $-11.2 \%$. In rural areas, the proportion of people speaking Ukrainian remained higher than in the cities (Results of population census 1999, Results of population census 2009, Results of population census 2019).

Women named Ukrainian as their mother tongue more often $-30.2 \%$, men $-28 \%$. The share of men for whom the mother tongue was the Russian language equaled $47.5 \%$ among the rural Ukrainian rural population and up to $66.9 \%$ among the urban population, whereas among women this parameter was $44.2 \%$ and $64.8 \%$ respectively. A similar situation exists with Belarusian language: in cities it was mother tongue for $6.7 \%$ of the Ukrainians. Over 3\% of the Ukrainians named the Ukrainian as the language of home communication. This parameter was the highest in Brest Oblast $-7.7 \%$, the lowest $-1.6 \%$ - in the city of Minsk. Almost half of the Ukrainians did not speak other languages $-48.4 \%$. Among fluently spoken languages, Ukrainians most often mentioned Ukrainian (14.4\%) and Belarusian (18\%). The Russian language was named as a fluently spoken language by $5.62 \%$ of the Ukrainians.

The most recent census of the country's population in 2019 indicated significant language assimilation of the Ukrainians (dynamics of ethnic language correspondence of Ukrainians by mother tongue and home language according to censuses carried out in 1999, 2009 and 2019 are given in Tables 1-2).

Table 1. Dynamics of ethnolinguistic correspondence of Ukrainians (mother tongue) according to censuses of 1999, 2009 and 2019

\begin{tabular}{|c|c|c|c|c|}
\hline \multirow{2}{*}{ Year of census } & \multirow{2}{*}{$\begin{array}{c}\text { Number of } \\
\text { Ukrainians }\end{array}$} & \multicolumn{3}{|c|}{ Mother tongue } \\
\cline { 3 - 5 } & Ukrainian & Russian & Belarusian \\
\hline 1999 & 237,014 & 42.8 & 42.8 & 14.3 \\
\hline 2009 & 158,723 & 29.2 & 61.2 & 7.9 \\
\hline 2019 & 159,656 & 29.1 & 62.4 & 8.2 \\
\hline
\end{tabular}

Table 2. Dynamics of ethnolinguistic correspondence of Ukrainians (language they speak at home) according to censuses of 1999, 2009 and 2019.

\begin{tabular}{|c|c|c|c|c|}
\hline \multirow{2}{*}{ Year of census } & \multirow{2}{*}{$\begin{array}{c}\text { Number of } \\
\text { Ukrainians }\end{array}$} & \multicolumn{3}{|c|}{ Home language } \\
\cline { 3 - 5 } & Ukrainian & Russian & Belarusian \\
\hline 1999 & 237,014 & 6.2 & 83.5 & 10.2 \\
\hline 2009 & 158,723 & 3.5 & 88.4 & 6.1 \\
\hline 2019 & 159,656 & 4.0 & 89.1 & 6.5 \\
\hline
\end{tabular}

Tables 1 and 2 indicate that changes and ethnic language criteria throughout the period of 2009-2019 were smaller compared with the period 1999-2009. This may to some extent be explained by the change in the generations and types of areas where Ukrainians were living at the moment of census. Increase in the ur- banization level in Belarus in general and in the environment of the Ukrainians in particular leads to faster transfer of Ukrainians to other languages in large cities, and mixed marriages and staying in a setting where another language is spoken only accelerate this process. 
Similar is the situation with the criterion "Language spoken at home".

\section{Conclusions.}

Despite the insignificant increase in the number of Ukrainians which was recorded by the 2019 census, the overall populationof Belarus and the Ukrainian diaspora correspond to the parameters of 1959. Despite the fact that Belarus includes ethnic Ukrainian territories, the share of Ukrainians in the country's population is stably low and does not exceed $2 \%$. Areas densely inhabited by Ukrainians are the southwest part of the country, oblast centers and a number of district centers outside the ethnic Ukrainian territories. Compared with 2009, the level of urbanization of the Ukrainian diaspora has increased (to the highest degree in districts north of Minsk), though in over 50 districts the Ukrainians predominantly live in villages. The Ukrainian diaspora in Belarus experiences outflow of Ukrainians from the border districts to the center of the country. Most often, the centers of "attraction" of Ukrainians are the capital, some oblast centers, more rarely district cen-

\section{Referenses}

Dnistrjans'kyj, M. S., 2008. Etnogeografija Ukrai'ny [Ethnogeography of Ukraine]. Vydavnychyj centr LNU imeni Ivana Franka, L’viv (In Ukrainian).

Ethnic composition of the population of Belarus according to the 1999 census. Retrieved from http://pop-stat.mashke. org/belarus-ethnic1999.htm (In Belorussian).

Ethnic composition of the population of Belarus according to the 2009 census. Retrieved from http://pop-stat.mashke. org/belarus-ethnic2009.htm (In Russian).

Ethnic composition of the population of Belarus according to the 2019 census. Retrieved from http://pop-stat.mashke. org/belarus-ethnic2019.htm (In Russian).

Results of population census 1999 (table data). National Statistical Committee of the Republic of Belarus. Retrieved from https://www.belstat.gov.by/informatsiyadlya-respondenta/perepis-naseleniya/perepis-naseleniya1999-goda/tablichnye-dannye/ (In Russian).

Results of population census., 2009. National Statistical Committee of the Republic of Belarus. Retrieved from https:/www.belstat.gov.by/informatsiya-dlyarespondenta/perepis-naseleniya/perepis-naseleniya2009-goda/(In Russian). ters, as indicated by the analysis of the dynamics of the number of Ukrainians during the period between the censuses of 2009-2019. Particularly, we determined that the greatest relative changes (toward increase) during that period occurred in the strip of districts between Minsk and Novopolotsk with ramification in the direction of the Belarus-Lithuania border on one side and a number of districts between Minsk toward Babbruysk and Mogilev. Analysis of a number of mathematical-statistical parameters confirmed that Belarus is a monoethnic country. Those parameters are lower in places that are densely populated by other ethnicities and a number of border districts. We can state that the relatively close cultural distance between Ukrainians, Belarusians and Russians in Belarus has no effect on the ethnic identification of Ukrainians, though Ukrainians in Belarus do experience Russianization. Also, we have to note that the changes according to ethnic language criteria during the inter-census period of 2009-2019 were less significant compared with the period of 1999-2009.

Results of population census 2019. National Statistical Committee of the Republic of Belarus. Retrieved from https://www.belstat.gov.by/informatsiya-dlyarespondenta/perepis-naseleniya/perepis-naseleniyaraunda-2020-goda/itogi-perepisi-naseleniya-respublikibelarus-2019-goda/ (In Russian).

Troshhyns'kyj, V. P., 1999. Ukrai'nci v sviti [Ukrainians in the world]. Al'ternatyvy, Kyiv (in Ukrainian).

Vynnychenko, I. I., 1992. Ukrai'nci v derzhavah kolyshn'ogo SRSR: istoryko-geografichnyj narys [Ukrainians in states of former USSR: historic-geographical essay]. L'onok, Zhytomyr (In Ukrainian).

Yevtukh V. B., 2012. Etnichnist': entsyklopedychnyy dovidnyk [Ethnicity: an encyclopedic reference book]. Feniks, Kyyiv (In Ukrainian).

Zastavnyj, F. D., 1992. Shidna ukrai'ns'ka diaspora [East Ukrainian diaspora]. Svit, L'viv (In Ukrainian).

Zubyk, A. I., 2019. Ukrai'ns'ka diaspora: suspil'nogeografichne doslidzhennja [Ukrainian diaspora: sociogeographical research]. Prostir-M, L’viv (In Ukrainian). 